\title{
Prevalensi Gejala Gangguan Gastrointestinal Pada Pasien Penyakit Parkinson
}

\section{Prevalence Of Gastrointestinal Symptoms On Parkinson's Disease Patients At Bethesda Hospital, Yogyakarta}

Rizaldy Taslim Pinzon, Abraham Al Jody, Sugianț

Faculty of Medicine, Kristen Duta Wacana University, Yogyakarta

\author{
KATAKUNCI Penyakit Parkinson, gejala non-motor, gastrointestinal, \\ prevalensi \\ KEYWORDS Parkinson's disease, non-motor symptom, gastrointestinal, \\ prevalence
}

ABSTRAK Gejala gastrointestinal merupakan salah satu gejala non-motor yang sering dialami oleh pasien penyakit Parkinson. Di Indonesia, terkhusus Yogyakarta, belum ada penelitian yang mencari angka prevalensi tersebut. Non-motor symptom assessment scale for Parkinson's disease (NMSS) merupakan salah satu instrumen yang mampu menyaring gejala tersebut. Mencari angka prevalensi gejala gangguan gastrointestinal pasien penyakit Parkinson di Rumah Sakit, Bethesda, Yogyakarta.

Penelitian ini adalah penelitian observatif deskriptif dengan disain potong lintang. Tiga puluh satu pasien penyakit Parkinson di Rumah Sakit Bethesda, Yogyakarta, diambil dengan teknik consecutive sampling, selanjutnya diwawancarai menggunakan kuisioner NMSS. Hasil wawancara dianalisis dengan analisa univariat.

Dari 31 sampel, didapatkan gejala gangguan gastrointestinal dialami oleh 17 (54,8\%) sampel. Urutan gejala gangguan gastrointestinal yang paling banyak ditemukan adalah konstipasi $(41,93 \%)$, sialorea $(29,03 \%)$, dan kesulitan menelan $(6,45 \%)$.

Didapatkan 54,8\% sampel mengalami gejala gangguan gastrointestinal, dengan urutan gejala yang paling banyak ditemukan adalah konstipasi, sialorea, dan kesulitan menelan.

ABSTRACT Gastrointestinal symptoms is one of the non-motor symptoms which is frequently associated with Parkinson's disease's patients. In Indonesia, specifically Yogyakarta City, no research that aim to find the prevalence of the gastrointestinal symptoms 
yet. Non-motor assessment scale for Parkinson's disease (NMSS) is one of the instruments that can filter the aforementioned symptom.

To find the prevalence of gastrointestinal symptoms of Parkinson's disease's patients at Bethesda Hospital, Yogyakarta This is a observative descriptive study, with cross-sectional design. Thirty one Parkinson's disease patients at Bethesda Hospital, Yogyakarta, were taken by consecutive sampling, which then interviewed using NMSS questionnaire. The results of the interview was analyzed by using univariate analysis.

From 31 samples, it is found that gastrointestinal symptoms were experienced in 17 of the total samples $(54,8 \%)$. By order, the most frequent gastrointestinal symptoms are constipation $(41,93 \%)$, sialorrhea $(29,03 \%)$, and difficulty of swallowing $(6,45 \%)$.

It is found that $54,8 \%$ of the samples have experienced gastrointestinal symptoms, with the most frequent symptom, by order, are constipation, sialorrhea, and difficulty of swallowing.

\section{PENDAHULUAN}

Penyakit Parkinson adalah salah satu penyakit pada sistem saraf yang telah banyak diketahui, dengan penyebab yang masih belum diketahui secara pasti. Penyakit Parkinson adalah penyakit neurodegeneratif dengan insidensi paling banyak setelah penyakit Alzheimer (Goldman L et al., 2016). Dewasa ini, penyakit Parkinson dipahami sebagai suatu penyakit neurodegeneratif progresif yang dapat ditemukan tanda dan gejala motor, nonmotor, dan perilaku (Pinzon RT dan Adnyana KSG 2016). Selain gejala utama motorik pada penyakit Parkinson, terdapat gejala-gejala lain yang dapat dirasakan oleh penderita penyakit Parkinson, yaitu gejala-gejala nonmotor. Perdossi (2015) mengungkapkan, walaupun gejalagejala motor merupakan indikator diagnosis penyakit Parkinson, gejalagejala non-motor merupakan gejala- gejala yang penting dan lazim dalam menentukan kualitas hidup pasien penyakit Parkinson. Gejala-gejala nonmotor dapat timbul sebelum munculnya gejala-gejala motor, yang nantinya akan membuat para klinisi mengalami kesulitan dalam proses pengobatan.

$$
\text { Menurut Quigley }
$$
gangguan gastrointestinal dalam suatu penyakit neurologis seringkali dilaporkan sebagai manifestasi dari gangguan motilitas saluran pencernaan. Gejala-gejala gastrointestinal tersebut seringkali terlewat dalam proses anamnesis, dan pada akhirnya berpengaruh terhadap kualitas hidup dari pasien penyakit Parkinson.

Correspondence:

Rizaldy Taslim Pinzon, Faculty of Medicine, Kristen Duta Wacana University, Yogyakarta.

Email:drpinzon17@gmail.com 
Su (2017) juga menyatakan, bahwa gejala-gejala gastrointestinal merupakan salah satu gejala non-motor penyakit Parkinson yang paling sering ditemukan pada pasien, serta salah satu yang paling mengganggu aktivitas kehidupan sehari-hari. Untuk mengetahui prevalensi dari gejala gangguan gastrointestinal, dapat digunakan beberapa instrumen pengukur. Salah satu contohnya adalah non-motor symptom assesment scale for Parkinson's disease.

Di Indonesia masih belum ada penelitian yang bertujuan mencari angka prevalensi gejala gastrointestinal pada pasien penyakit Parkinson di Yogyakarta. Hal inilah yang membuat peneliti ingin meneliti lebih lanjut mengenai angka prevalensi gejala gastrointestinal pada pasien penyakit Parkinson di Rumah Sakit Bethesda Yogyakarta.

\section{METODE}

Penelitian ini merupakan penelitian observasional deskriptif menggunakan disain penelitian potong lintang. Sebanyak 31 pasien penyakit Parkinson di Rumah Sakit Bethesda, Yogyakarta, diambil sebagai sampel penelitian. Pengambilan sampel dilakukan dengan melakukan sampling beruntun (consecutive sampling). Penelitian diadakan selama periode Januari-Maret 2018. Data yang dipakai pada penelitian ini adalah data primer, dengan menanyakan langsung melalui wawancar kepada setiap sampel. Sampel disaring dengan kriteria inklusi yaitu semua pasien penyakit Parkinson yang berusia diatas 40 tahun, laki-laki maupun perempuan, dan bersedia untuk berpartisipasi pada penelitian ini. Kriteria eksklusi adalah pasien yang mengalami gangguan fungsi komunikasi, serta pasien Parkinson dengan demensia dan atau gangguan bicara.

Setiap sampel akan ditanyakan beberapa pertanyaan, yang didalamnya termasuk pertanyaan-pertanyaan dari kuisioner NMSS. Tiap pasien menjelaskan mengenai frekuensi dan keparahan dari setiap gejala yang ditanyakan. Hasil wawancara dari semua sampel kemudian dianalisis menggunakan analisis univariat. Studi ini telah disetujui oleh Komite Etik Penelitian Kesehatan Fakultas Kedokteran Universitas Kristen Duta Wacana dengan nomor 605/C.16/FK/2018.

\section{HASIL}

Didapatkan karakteristik dasar dari sampel penelitian ini seperti dapat dilihat pada tabel 1. Sejumlah 31 pasien penyakit Parkinson dimasukkan sebagai sampel dalam penelitian ini. Kebanyakan sampel adalah pasien lakilaki $(54,8 \%)$, dengan mayoritas sampel berusia lebih dari 70 tahun (45,1\%). Durasi sakit penyakit Parkinson dari sampel, didapatkan paling banyak berada pada rentang 1-2 tahun (41,9\%). Stadium penyakit paling banyak pada stadium III (64,5\%). Pengobatan untuk penyakit Parkinson yang sering dipakai adalah campuran obat-obatan bergolongan levodopa dan nonlevodopa $(54,8 \%)$.

Berdasarkan riwayat penyakit pasien, diketahui 27 pasien memiliki komorbid $(87,1 \%)$. Urutan komorbid yang paling sering ditemukan adalah stroke $(74,2 \%)$, hipertensi $(35,5 \%)$, diabetes mellitus $(25,8 \%)$, penyakit jantung iskemik (16,1\%), epilepsi $(9,7 \%)$, hernia nukleus pulposus $(6,5 \%)$, vertigo $(3,2 \%)$, dan penyakit paru obstruktif kronis $(3,2 \%)$. 
Tabel 1. Karakteristik Dasar Pasien Penyakit Parkinson

\begin{tabular}{|c|c|c|}
\hline Variabel & Jumlah $(\mathrm{n}=31)$ & Persentase $(\%)$ \\
\hline \multicolumn{3}{|l|}{ Usia } \\
\hline 40-50 tahun & 1 & $3,3 \%$ \\
\hline 51-60 tahun & 3 & $9,7 \%$ \\
\hline 61-70 tahun & 13 & $41,9 \%$ \\
\hline$>70$ tahun & 14 & $45,1 \%$ \\
\hline \multicolumn{3}{|l|}{ Jenis kelamin } \\
\hline Laki - laki & 17 & $54,8 \%$ \\
\hline Perempuan & 14 & $45,2 \%$ \\
\hline \multicolumn{3}{|l|}{ Stadium Hoehn - Yahr } \\
\hline Stadium I & - & $0 \%$ \\
\hline Stadium II & 9 & $29 \%$ \\
\hline Stadium III & 20 & $64,5 \%$ \\
\hline Stadium IV & 2 & $6,5 \%$ \\
\hline Stadium V & - & $0 \%$ \\
\hline \multicolumn{3}{|l|}{ Durasi Sakit } \\
\hline$<1$ tahun & 3 & $9,7 \%$ \\
\hline 1-2 tahun & 13 & $41,9 \%$ \\
\hline $2-3$ tahun & 10 & $32,3 \%$ \\
\hline$>3$ tahun & 5 & $16,1 \%$ \\
\hline \multicolumn{3}{|l|}{ Obat anti - Parkinson } \\
\hline Levodopa & 13 & $41,9 \%$ \\
\hline Non-Levodopa & 1 & $3,3 \%$ \\
\hline Levodopa+Non-Levodopa & 17 & $54,8 \%$ \\
\hline \multicolumn{3}{|l|}{ Komorbid } \\
\hline Tidak & 4 & $12,9 \%$ \\
\hline Ya & 27 & $87,1 \%$ \\
\hline \multicolumn{3}{|l|}{ Stroke } \\
\hline Tidak & 8 & $25,8 \%$ \\
\hline Ya & 23 & $74,2 \%$ \\
\hline \multicolumn{3}{|l|}{ Hipertensi } \\
\hline Tidak & 20 & $64,5 \%$ \\
\hline Ya & 11 & $35,5 \%$ \\
\hline \multicolumn{3}{|l|}{ Diabetes Mellitus } \\
\hline Tidak & 23 & $74,2 \%$ \\
\hline $\mathrm{Ya}$ & 8 & $25,8 \%$ \\
\hline \multicolumn{3}{|l|}{ Penyakit Jantung Iskemik } \\
\hline Tidak & 26 & $83,9 \%$ \\
\hline $\mathrm{Ya}$ & 5 & $16,1 \%$ \\
\hline \multicolumn{3}{|l|}{ Epilepsi } \\
\hline Tidak & 28 & $90,3 \%$ \\
\hline $\mathrm{Ya}$ & 3 & $9,7 \%$ \\
\hline \multicolumn{3}{|l|}{ HNP } \\
\hline Tidak & 29 & $93,5 \%$ \\
\hline $\mathrm{Ya}$ & 2 & $6,5 \%$ \\
\hline \multicolumn{3}{|l|}{ Vertigo } \\
\hline Tidak & 30 & $96,8 \%$ \\
\hline Ya & 1 & $3,2 \%$ \\
\hline \multicolumn{3}{|l|}{ PPOK } \\
\hline Tidak & 30 & $96,8 \%$ \\
\hline $\mathrm{Ya}$ & 1 & $3,2 \%$ \\
\hline
\end{tabular}


Didapatkan 17 dari 31 subyek penelitian $(54,8 \%)$ mengalami gejala gangguan gastrointestinal. Gejala yang paling sering dirasakan adalah konstipasi $(41,93 \%)$, diikuti oleh sialorea $(29,03 \%)$ dan gangguan menelan $(6,45 \%)$. Tidak didapatkan perbedaan distribusi gejala yang signifikan pada laki-laki atau perempuan. Penyebaran gejala juga didapatkan paling banyak terjadi pada subyek yang berusia lebih dari 60 tahun. Penelitian ini juga mendapatkan penyebaran gejala paling banyak didapatkan pada subyek yang mengalami penyakit Parkinson selama 1-2 tahun. Selain itu, dari hasil penelitian ditemukan subyek mengalami gejala gangguan gastrointestinal kebanyakan berada dalam stadium 3 Hoehn-Yahr. Berdasarkan obat-obatan yang dikonsumsi, subyek yang menggunakan obat golongan levodopa, tunggal ataupun kombinasi, memiliki persentase lebih besar dalam mengalami gejala gangguan gastrointestinal.

Tabel 2. Distribusi Gejala Gangguan Gastrointestinal terhadap Jenis Kelamin

\begin{tabular}{lccc}
\hline \multirow{2}{*}{$\begin{array}{l}\text { Gejala Gangguan } \\
\text { Gastrointestinal }\end{array}$} & \multicolumn{2}{c}{ Jenis Kelamin } & \multirow{2}{*}{$\begin{array}{c}\text { Total } \\
(\mathrm{n}=31)\end{array}$} \\
\cline { 2 - 3 } Sialorea & Laki-laki & Perempuan & \\
Gangguan & 4 & 5 & 9 \\
menelan & $(12,9 \%)$ & $(16,13 \%)$ & $(29,03 \%)$ \\
Konstipasi & 2 & & 2 \\
& $(6,45 \%)$ & - & $(6,45 \%)$ \\
& 6 & 7 & 13 \\
& $(19,35 \%)$ & $(22,58 \%)$ & $(41,93 \%)$ \\
\hline
\end{tabular}

Tabel 3. Distribusi Gejala Gangguan Gastrointestinal terhadap Usia

\begin{tabular}{|c|c|c|c|c|c|}
\hline \multirow{2}{*}{$\begin{array}{c}\text { Gejala Gangguan } \\
\text { Gastrointestinal }\end{array}$} & \multicolumn{4}{|c|}{ Usia (tahun) } & \multirow{2}{*}{$\begin{array}{l}\text { Total } \\
(\mathrm{n}=31)\end{array}$} \\
\hline & $40-50$ & $51-60$ & $61-70$ & $>70$ & \\
\hline Sialorea & - & $\begin{array}{c}1 \\
(3,23 \%)\end{array}$ & $\begin{array}{c}5 \\
(16,13 \%)\end{array}$ & $\begin{array}{c}3 \\
(9,68 \%)\end{array}$ & $\begin{array}{c}9 \\
(29,03 \%)\end{array}$ \\
\hline $\begin{array}{l}\text { Gangguan } \\
\text { menelan }\end{array}$ & - & - & $\begin{array}{c}1 \\
(3,23 \%)\end{array}$ & $\begin{array}{c}1 \\
(3,23 \%)\end{array}$ & $\begin{array}{c}2 \\
(6,45 \%)\end{array}$ \\
\hline Konstipasi & $\begin{array}{c}1 \\
(3,23 \%)\end{array}$ & $\begin{array}{c}1 \\
(3,23 \%)\end{array}$ & $\begin{array}{c}3 \\
(9,68 \%) \\
\end{array}$ & $\begin{array}{c}8 \\
(25,81 \%) \\
\end{array}$ & $\begin{array}{c}13 \\
(41,93 \%) \\
\end{array}$ \\
\hline
\end{tabular}


Tabel 4. Distribusi Gejala Gangguan Gastrointestinal terhadap Durasi Penyakit Parkinson

\begin{tabular}{lccccc}
\hline \multirow{2}{*}{$\begin{array}{l}\text { Gejala Gangguan } \\
\text { Gastrointestinal }\end{array}$} & \multicolumn{4}{c}{$\begin{array}{c}\text { Durasi Penyakit } \\
\text { (tahun) }\end{array}$} & $\begin{array}{c}\text { Total } \\
(\mathrm{n}=31)\end{array}$ \\
\cline { 2 - 5 } & $<1$ & $1-2$ & $2-3$ & $>3$ & \\
\hline Sialorea & 2 & 6 & & 1 & 9 \\
Gangguan & $(6,45 \%)$ & $(19,35 \%)$ & - & $(3,23 \%)$ & $(29,03 \%)$ \\
menelan & 1 & 1 & & - & 2 \\
Konstipasi & $(3,23 \%)$ & $(3,23 \%)$ & - & & $(6,45 \%)$ \\
& 2 & 9 & - & 2 & 13 \\
& $(6,45 \%)$ & $(29,03 \%)$ & & $(6,45 \%)$ & $(41,93 \%)$ \\
\hline
\end{tabular}

Tabel 5. Distribusi Gejala Gangguan Gastrointestinal terhadap Stadium Penyakit Parkinson

\begin{tabular}{lcccccc}
\hline $\begin{array}{l}\text { Gejala Gangguan } \\
\text { Gastrointestinal }\end{array}$ & \multicolumn{4}{c}{$\begin{array}{c}\text { Stadium Penyakit Parkinson } \\
\text { (Hoehn dan Yahr) }\end{array}$} & \multirow{2}{*}{$\begin{array}{c}\text { Total } \\
(\mathrm{n}=31)\end{array}$} \\
\cline { 2 - 5 } & 1 & 2 & 3 & 4 & 5 & \\
\hline Sialorea & - & 3 & 5 & 1 & - & 9 \\
Gangguan & & $(9,68 \%)$ & $(16,13 \%)$ & $(3,23 \%)$ & $(29,03 \%)$ \\
menelan & - & - & 2 & & - & 2 \\
Konstipasi & - & 2 & $(6,45 \%)$ & - & - & $(6,45 \%)$ \\
& & $(6,45 \%)$ & $(32,26 \%)$ & $(3,23 \%)$ & - & 13 \\
& & & & 10 & 1 & \\
\end{tabular}

Tabel 6. Distribusi Gejala Gangguan Gastrointestinal terhadap Jenis Pengobatan Penyakit Parkinson

\begin{tabular}{lcccc}
\hline Gejala Gangguan & \multicolumn{3}{c}{ Jenis Pengobatan Penyakit Parkinson } & Total \\
\cline { 2 - 4 } Gastrointestinal & Levodopa & Non-Levodopa & Levodopa + Non-Levodopa & $(\mathrm{n}=31)$ \\
\hline Sialorea & 4 & 1 & 4 & 9 \\
Gangguan & $(12,9 \%)$ & $(3,23 \%)$ & $(12,9 \%)$ & $(29,03 \%)$ \\
menelan & 1 & 1 & - & 2 \\
Konstipasi & $(3,23 \%)$ & $(3,23 \%)$ & 7 & $(6,45 \%)$ \\
& 6 & - & $(22,58 \%)$ & 13 \\
\hline
\end{tabular}


